\title{
BEHAVIOR OF HOLLOW I-BEAMS REACTIVE POWDER CONCRETE WITH OPENING FOR PURE TORQUE
}

\author{
ALI SABAH AHMED ALAMLI ${ }^{1} \&$ SARMAD HAITHAM ABDULAMEER ${ }^{2}$ \\ ${ }^{1}$ Assistant Professor, Civil Engineering Department, AlMustansiriyah Engineering College, \\ Almustansiriyah University, Baghdad, Iraq \\ ${ }^{2}$ M.Sc. Student, Civil Engineering Department, AlMustansiriyah Engineering College,
}

Almustansiriyah University, Baghdad, Iraq

\begin{abstract}
A series of nine, I section reinforced concrete hollow beams, by use of Reactive Powder Concrete (RPC), with square and circular web opening. The geometry and main reinforcement of all specimens are same, and was investigated under the effect of pure torsion. The main parameters taking into account, in present paper are hollow beam size, the location of hollow opening geometry and opening size. The torque caused the first crack, that was recorded and the angle of twist generated from this torque, was calculated for different parameters mentioned above. The results indicated that, the crack torques for a first crack decrease in presence of hollow and opening, and the crack torques decrease when the size of hollow and opening increased.
\end{abstract}

KEYWORDS: Torque, RPC, Hollow Beams, Hollow Beams with Web Opening \& I- Section

Received: Aug 19, 2017; Accepted: Sep 06, 2017; Published: Sep 16, 2017; Paper Id.: IJCSEIERDOCT20177

\section{INTRODUCTION}

A reinforced concrete beam has cracked in torsion, its torsional resistance is provided primarily by closed stirrups and longitudinal bars, located near the surface of the member [1]. A hollow beam and opening in the web has many advantages, in modern structural design. Introduced opening like circular, square, and rectangular or any shape has advantages, to use it to pass services and hollow beams are most widely, known for economic benefits, for long span bridges, hollow beams are a normal solution for the cross section. A Longitudinal opening is used to construct hollow core beams cast in the site, precast and pre stressed concrete member with continuous voids provided to reduce weight and, therefore, cost and, as a side benefit, to use for hidden electrical or mechanical work. The applications of structural hollow sections almost cover all fields. The size and location of hollow beams, shape and size of web opening, relay on the purpose of opening, but the presence of opening reduce the stiffness of the beam and the opening make the deflections higher, when compared with solid web.

Reactive Powder Concrete (RPC), improved the important properties of concrete that is compressive strength, tensile strength, flexural strength and Young's modulus of elasticity, Torsional resistance of RC beams, by using closed stirrups and main reinforcement, at the sides. In 2015, Hisham Mohamed et al, [2], tested and investigated the behavior of ten reinforced concrete specimens of $\mathrm{T}$ sections, with and without hole along the span under pure torsion, and using reactive powder. Authors focused on the effects of holes and steel fibers, on the cracks and full capacity of $\mathrm{T}$ sections, under pure torsion. By results from experimental tests increased in capacity, for solid section is more, if compared with hollow section in case of presence of steel fibers, but the core has no 
effect on the ultimate torsion capacity. In 2015, Waleed Awad et al, [3], studied the ultimate strength of hollow RC beams, under pure torsion. The investigation consists of solid and hollow section, with eighteen percent for circular opening and eighteen and twenty seven percent for rectangular opening, from the total depth of beams. Torque - twist and opening effects on it, and on the full behavior of RCC beams, discussed by authors. Researchers concluded that, the full capacity torque of hollow section in case of circular is greater than, in case of rectangular hollow, when compared with solid section. In 2015, Hisham Mohamed et al, [4], suggested an empirical formula, by using regression method to estimate torsional capacity in case of, presence steel fiber. The two proposed formula deals with codes formula and derived from tests result. In 2015, Haneen Maad [5], investigated the behavior of High Strength Self Compacted "HSSC", of hollow section RCC beams, under pure torsion. The total six beams were tested, and have same geometry and length, so, the main variables were in the stirrups spacing. The experimental tests result indicated that, the torsion beams resistance increased by decreasing of stirrups spacing, also, the improvements of ultimate torsional capacity, compared with reference beam up to two hindered fifty percent, and for torsional cracks up to two hindered percent. In 2013, Wissam Kadhum [6[, investigate RPC beams, subjected to pure torsion by which, we tested the strength capacity and torsional cracks of beams, experimentally and theoretically. The experimental work consists of twenty two T section of RPC, with various fiber steel ratios and silica fume subjected, to pure torsion. Theoretical approach using tests results and proposed empirical equations, represent cracking torque as a function of properties of RPC, and another proposed equation, to estimate maximum torsion relay on the properties of RPC. Test results indicated that, in presence and using of RPC up to (2\%), increased the cracking torsion and then increased in full torsional capacity. In 2013, Raid I. Khalel [7], investigated RC beams under pure torsion, in case of high strength concrete type. Forty three specimens were adopted by author from literature review, and applied regressions method to suggest an empirical equations, cracked due to pure torsion and resistance, or torsional capacity as a function of concrete compressive strength, geometry longitudinal and transverse reinforcement. In 2012, Raed Hamed [8], investigated the behavior of RC beams, in presence of steel fibers and self-compact under pure torsional loading. Angle of twist and strain, resulted from applied torsion was compared for all concrete types. In 2010, Wameedh Ghassan [9], investigated the torsional capacity of tested reinforced concrete "RC" beams, as a function of various variables like fibers amount, with and without openings, and reinforcement ratio in each directions. The researcher founded that, adding one percent of steel fiber increased the torque and reduced cracking.

\section{EXPERMINTAL STUDY}

\section{Experimental Program}

The main variables adopted in the experimental work as follow; reactive powder concrete (RPC). Nine reinforced concrete beams of I-section have been cast, and then tested under pure torsion, one of them was solid and four with hollow only, and the others with hollow and web opening. The sections of I-beam are designed according to ACI 318M-14 [1], the opening in this study contains many variables in shape and dimension, and the hollow contains variables in size and location.

Table 1 shows beam designations and the division of samples: 
Table 1: General Details and Variable of Specimen

\begin{tabular}{|c|c|c|c|}
\hline Beam No. & Name of beam & $\begin{array}{l}\text { Dimension of Opening } \\
\text { and Hollow (mm) }\end{array}$ & $\begin{array}{c}\text { Location of Opening } \\
\text { and Hollow }\end{array}$ \\
\hline BT1 & I-beam solid (reference) & - & 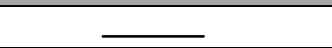 \\
\hline BT2 & I-beam with a hollow at the centre of the web. & $\begin{array}{c}* \mathrm{H}=30 \\
\mathrm{~mm}\end{array}$ & Center \\
\hline BT3 & I-beam with a hollow at the centre of the web. & $\begin{array}{c}* \mathrm{H}=50 \\
\mathrm{~mm}\end{array}$ & Center \\
\hline \multirow{2}{*}{ BT4 } & \multirow{2}{*}{$\begin{array}{l}\text { I-beam with a hollow at }(1 / 4) \text { depth of the web } \\
\text { and square opening at }(3 / 4) \text { depth of the web } \\
\text { at the centre of the beam. }\end{array}$} & $* \mathrm{~A}=(60 * 60) \mathrm{mm} 2$ & $\begin{array}{c}\text { (3/4 depth } \\
\text { \& Mid span) }\end{array}$ \\
\hline & & $\begin{array}{c}* \mathrm{H}=30 \\
\mathrm{~mm}\end{array}$ & (1/4) depth \\
\hline BT5 & $\begin{array}{l}\text { I-beam with a hollow at (1/4) depth of the } \\
\text { web. }\end{array}$ & $\begin{array}{c}* \mathrm{H}=50 \\
\mathrm{~mm}\end{array}$ & (1/4) depth \\
\hline BT6 & $\begin{array}{l}\text { I-beam with a hollow at (1/4) depth of the } \\
\text { web. }\end{array}$ & $\begin{array}{c}* \mathrm{H}=30 \\
\mathrm{~mm}\end{array}$ & (1/4) depth \\
\hline \multirow[t]{2}{*}{ BT7 } & \multirow{2}{*}{$\begin{array}{l}\text { I-beam with a hollow at }(1 / 4) \text { depth of the web } \\
\text { and a circular opening at }(3 / 4) \text { depth of the } \\
\text { web at the centre of the beam. }\end{array}$} & $\begin{array}{c}* \mathrm{D}=60 \\
\mathrm{~mm}\end{array}$ & $\begin{array}{l}(3 / 4) \text { depth } \\
\text { \& Mid span }\end{array}$ \\
\hline & & $\begin{array}{c}* \mathrm{H}=30 \\
\mathrm{~mm}\end{array}$ & (1/4) depth \\
\hline \multirow{2}{*}{ BT8 } & \multirow{2}{*}{$\begin{array}{l}\text { I-beam with a hollow at }(1 / 4) \text { depth of the web } \\
\text { and square opening at }(3 / 4) \text { depth of the web } \\
\text { at the centre of the beam. }\end{array}$} & $* \mathrm{~A}=(40 * 40) \mathrm{mm} 2$ & $\begin{array}{l}\text { (3/4) depth } \\
\text { \& Mid span }\end{array}$ \\
\hline & & $\begin{array}{c}* \mathrm{H}=30 \\
\mathrm{~mm}\end{array}$ & (1/4) depth \\
\hline \multirow[t]{2}{*}{ BT9 } & \multirow{2}{*}{$\begin{array}{l}\text { I-beam with a hollow at }(1 / 4) \text { depth of the web } \\
\text { and a circular opening at }(3 / 4) \text { depth of the } \\
\text { web. at the centre of the beam. }\end{array}$} & $\begin{array}{c}* \mathrm{D}=40 \\
\mathrm{~mm}\end{array}$ & $\begin{array}{l}\text { (3/4) depth } \\
\text { \& Mid span }\end{array}$ \\
\hline & & $\begin{array}{c}* \mathrm{H}=40 \\
\mathrm{~mm}\end{array}$ & (1/4) depth \\
\hline
\end{tabular}

* A=area of opening, * $\mathrm{D}=$ diameter of opening, * $\mathrm{H}=$ diameter of hollow

\section{Specimen Details}

The dimensions of I-beam in the present study are $b w=120 \mathrm{~mm}, \mathrm{hw}=200 \mathrm{~mm}, \mathrm{bf}=270 \mathrm{~mm}$. $\mathrm{tf}=60 \mathrm{~mm}$, with the length of $(1500 \mathrm{~mm})$. The reinforcement for beams with stirrups as distributed with bottom flange reinforcement $2 \Phi 8$, top flange reinforcement $2 \Phi 8$ and in the web reinforcement 4Ф6, shear reinforcement $\Phi 6 @ 120 \mathrm{~mm}$, the total tested beams were nine beams, that have same geometry and steel reinforcement.

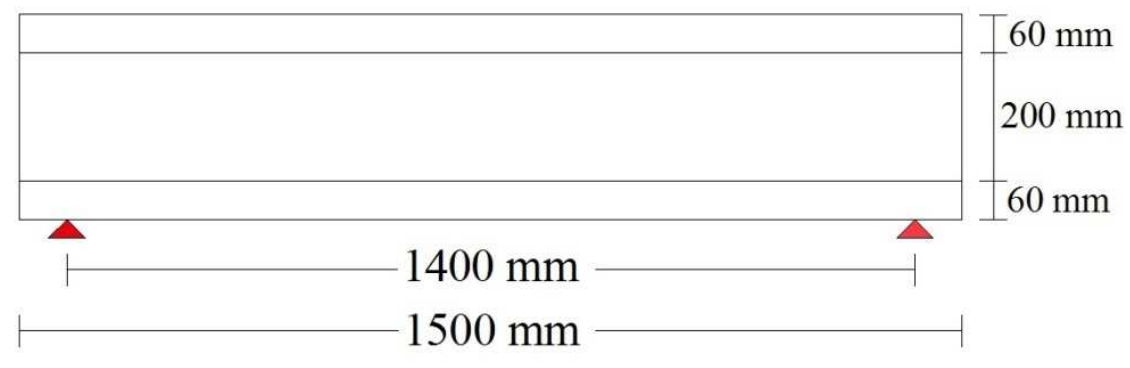

Figure 1: Solid I-Beam Specimen Details 


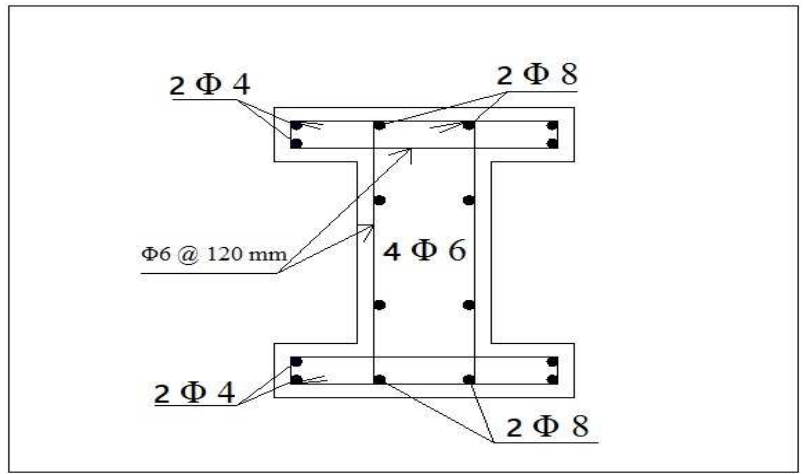

Figure 2: I-Beam Reinforcement Details
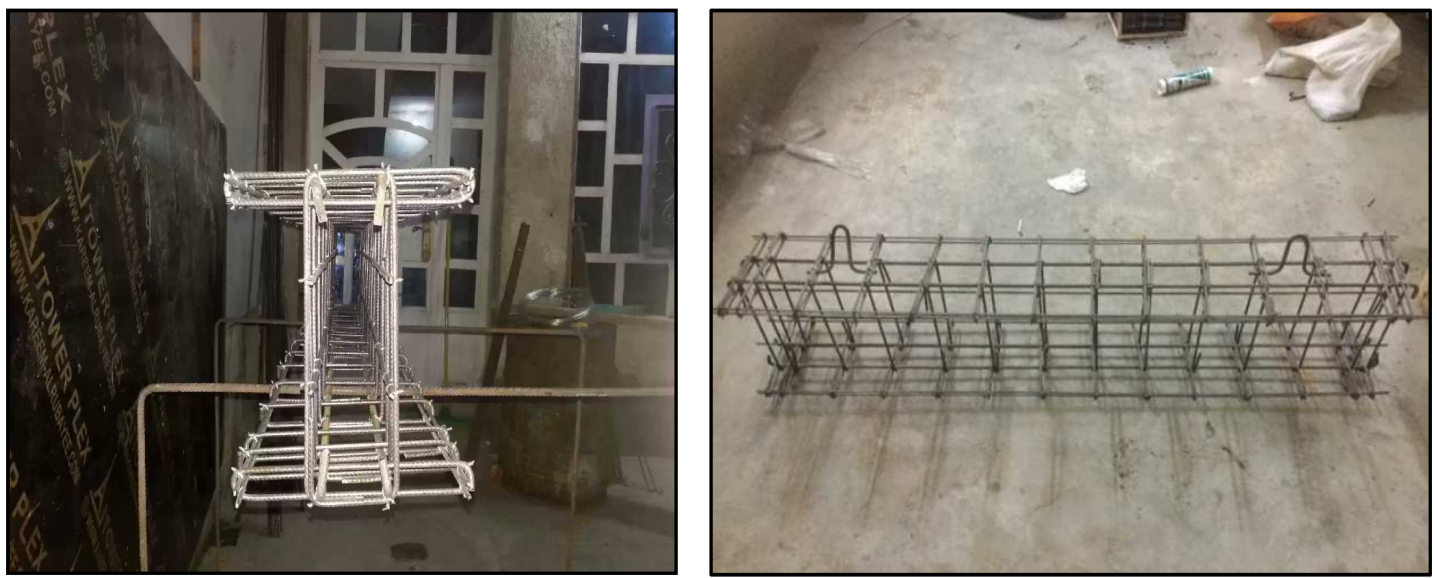

Figure 3: Photos of I-Beam Reinforcement Details

\section{MATERIAL}

Types of concrete mixes are used in Reactive Powder Concrete (RPC). The (RPC) mixes production requires high quality materials. Usually, chemical admixtures are employed to obtain a low water-cement (w/c) ratio, with acceptable workability.

\section{Cement}

Ordinary Portland cement type (I) Mass (Sulaymaniyah) in Iraq was used for (RPC). Tables 2, list the results of physical properties of the cement. Results indicate that, the available cement conforms to the Iraqi Specification (IQS) No.5/1984[10].

Table 2: Physical Properties of Cement

\begin{tabular}{|l|c|c|}
\hline \multicolumn{1}{|c|}{ Physical Properties } & $\begin{array}{c}\text { Test } \\
\text { Result }\end{array}$ & Limit of Iraqi Specification No.5/1984 \\
\hline $\begin{array}{l}\text { Specific surface area (Blaine } \\
\text { Method), m2/kg }\end{array}$ & 383 & $230(\mathrm{~min})$ \\
\hline Setting time (vicat's method) & $1: 55$ & $00: 45(\min )$ \\
Initial setting, hrs: min & $4: 25$ & $10: 00(\max )$ \\
Final setting, hrs: min & 25 & $15.00(\min )$ \\
\hline Compressive Strength, Mpa & 31 & $23.00(\min )$ \\
3 days & 0.01 & $0.8(\max )$ \\
\hline days & & \\
\hline Autoclave expansion \% & & \\
\hline
\end{tabular}




\section{Fine Aggregate}

Very fine sand with maximum size $600 \mu \mathrm{m}$ was used for (RPC). The grading of used fine sand conforms to the Iraqi specification (IQS) No.45/1984[11].

\section{Silica Fume}

The silica fume $(\mathrm{SiO} 2)$ reacts with this calcium hydroxide, to form additional binder material (calcium silicate hydrate $(\mathrm{C}-\mathrm{S}-\mathrm{H}))$, which is very similar to the calcium silicate hydrate, formed from the Portland cement [12]. In the present paper, Silica fume has (20\%) cement mass for (RPC) and (10\%), the chemical composition of this silica fume conforms to the ASTM 1240-04 [12]. High range water reducing agent HRWRA, based on poly carboxylic ether is used. One of the new generation of polymer based super plasticizer Glenium 51 is used, the normal dosage for it is (0.5-0.8) L/100kg of cement mass. It is free from chlorides and complies with ASTMC494 [13], types A and F.

\section{Steel Fibers}

Hooked ends short steel fibers were used in this work, with volume fractions of $\mathrm{Vsf}=1 \%$. The properties of the used steel fibers are shown in Table 3.

Table 3: Properties of the Steel Fibers

\begin{tabular}{|l|c|}
\hline \multicolumn{1}{|c|}{ Property } & Specifications \\
\hline Relative density & $7860 \mathrm{~kg} / \mathrm{m} 3$ \\
\hline Yield strength & $1130 \mathrm{Mpa}$ \\
\hline Modulus of elasticity & $200 \times 103 \mathrm{Mpa}$ \\
\hline Strain at portion limit & $5650 \times 10-6$ \\
\hline Poisson's ratio & 0.28 \\
\hline Average length & $32 \mathrm{~mm}$ \\
\hline Nominal diameter & $0.4 \mathrm{~mm}$ \\
\hline Aspect ratio & 80 \\
\hline
\end{tabular}

\section{Steel Reinforcement}

Three sizes of steel reinforcing bars were used in the tested beams, deformed bars of size, (Ф4, Ф6 \& $\Phi 8) \mathrm{mm}$ were used as longitudinal reinforcement, and deformed steel bars of size ( $\Phi$ 6)mm, were used as closed stirrups. The bars have been tested in the material laboratory of the Civil Engineering Department, at Al-Mustansiriyah University, test results of steel bars conform to (ASTM A615/615M-13) [14], the results listed in Table 4.

Table.4: Properties of Steel Bars

\begin{tabular}{|c|c|c|c|c|}
\hline $\begin{array}{c}\text { Nominal } \\
\text { Diameter }(\mathbf{m m})\end{array}$ & $\begin{array}{c}\text { Measured } \\
\text { Bar Diameter }(\mathbf{m m})\end{array}$ & $\begin{array}{c}\text { Yield Stress (fy) } \\
(\mathbf{M P a})\end{array}$ & $\begin{array}{c}\text { Ultimate } \\
\text { Stress(fu) (MPa) }\end{array}$ & $\begin{array}{c}\text { Elongation } \\
\%\end{array}$ \\
\hline 8 & 7.82 & 580 & 733 & 13.6 \\
\hline 6 & 6.06 & 666 & 912 & - \\
\hline 4 & 4.10 & 540 & 680 & - \\
\hline
\end{tabular}

\section{Mixing (RPC)}

Reactive powder concrete consisting of cement, fine sand, silica fume, steel fibers, super-plasticizers and water, were used to cast the RPC beams, as well as the control specimens (cubes, cylinders and prisms) of RPC. The composition of RPC with a water to cement ratio of 0.2 , percentage of silica fume was (20\%) by weight of cement, and very fine sand was used with maximum particles size of $(600 \mu \mathrm{m})$, Table 5 list concrete mix for (RPC). 
Table 5: Properties of Concrete Mix (RPC)

\begin{tabular}{|c|c|c|c|c|c|c|c|}
\hline $\begin{array}{c}\text { Cement } \\
\text { kg/m3 }\end{array}$ & $\begin{array}{c}\text { Sand } \\
\text { kg/m3 }\end{array}$ & $\begin{array}{c}\text { Silica } \\
\text { Fume* } \\
\%\end{array}$ & $\begin{array}{c}\text { Silica } \\
\text { Fume } \\
\text { kg/m3 }\end{array}$ & w/c & $\begin{array}{c}\text { Super } \\
\text { Plasticizer } \\
(\text { S.P) } \\
(\text { L/m3) }\end{array}$ & $\begin{array}{c}\text { Steel } \\
\text { Fiber } \\
\text { Content** } \\
\%\end{array}$ & $\begin{array}{c}\text { Steel Fiber } \\
\text { Content } \\
\text { kg/m3 }\end{array}$ \\
\hline 1000 & 1000 & 20 & 200 & 0.2 & 5 & 1 & 78 \\
\hline
\end{tabular}

* percent of weight cement

** Percent of mix volume.

\section{Classifications of Tested Specimens}

Table 6 listed the tested beams classifications, containing all geometry, hollow location, hollow size, hollow shape, opening sizes, opening geometry, compressive strength, cracked torque with angle of twist, and percentages of cracked torque from ultimate torque. Figure 1, show the tested beams layout, with all dimensions.

Table 6: Tested Beams Classifications

\begin{tabular}{|c|c|c|c|c|c|c|c|c|c|c|}
\hline $\begin{array}{l}\text { Specime } \\
\text { n Mark }\end{array}$ & $\begin{array}{l}\text { Hollow } \\
\text { Location }\end{array}$ & $\begin{array}{l}\text { Hollow } \\
\text { Size } \\
(\mathbf{m m})\end{array}$ & $\begin{array}{c}\text { Shape } \\
\text { of } \\
\text { Hollow }\end{array}$ & $\begin{array}{c}\text { Location } \\
\text { of } \\
\text { Opening }\end{array}$ & $\begin{array}{c}\begin{array}{c}\text { Size } \\
\text { of } \\
\text { Opening } \\
(\mathrm{mm})\end{array} \\
\end{array}$ & $\begin{array}{c}\text { Shape } \\
\text { of } \\
\text { Openin } \\
\text { g }\end{array}$ & $\begin{array}{c}\text { Fc* }^{*} \\
\text { (MPa) }\end{array}$ & $\begin{array}{c}\text { Crack } \\
\text { Torque } \\
\text { (kN.m) }\end{array}$ & $\begin{array}{c}\text { Angle } \\
\text { of } \\
\text { Twist } \\
\text { (Rad.) } \\
\end{array}$ & $\begin{array}{c}(\mathrm{Tcr} / \mathrm{Tu}) \\
\%\end{array}$ \\
\hline BT1 & ------ & ------- & ------ & ------ & ------ & ------ & 130 & 43.75 & $\begin{array}{c}0.005 \\
7\end{array}$ & 72.92 \\
\hline BT2 & $\begin{array}{l}\text { Center } \\
\text { of the } \\
\text { web }\end{array}$ & $* \mathrm{H}=(30)$ & Circular & ------- & ------- & ------ & 130 & 36.25 & $\begin{array}{c}0.004 \\
3\end{array}$ & 64.4 \\
\hline BT3 & $\begin{array}{l}\text { Center } \\
\text { of the } \\
\text { web }\end{array}$ & $* \mathrm{H}=(50)$ & Circular & ------- & ------- & ------ & 130 & 33.75 & $\begin{array}{c}0.006 \\
3\end{array}$ & 65.53 \\
\hline BT4 & $\begin{array}{l}(1 / 4) \\
\text { depth of } \\
\text { the web }\end{array}$ & $* \mathrm{H}=(30)$ & Circular & $\begin{array}{l}\text { Mid } \\
\text { Span }\end{array}$ & $\begin{array}{c}* A= \\
(60 * 60)\end{array}$ & Square & 130 & 28.75 & $\begin{array}{c}0.007 \\
93\end{array}$ & 68.86 \\
\hline BT5 & $\begin{array}{l}(1 / 4) \\
\text { depth of } \\
\text { the web }\end{array}$ & $* \mathrm{H}=(50)$ & Circular & ------- & ------- & ------- & 130 & 32.5 & 0.009 & 68.42 \\
\hline BT6 & $\begin{array}{l}(1 / 4) \\
\text { depth of } \\
\text { the web }\end{array}$ & $* \mathrm{H}=(30)$ & Circular & ------- & ------- & ------- & 130 & 31.75 & $\begin{array}{c}0.005 \\
1\end{array}$ & 59.62 \\
\hline BT7 & $\begin{array}{l}(1 / 4) \\
\text { depth of } \\
\text { the web }\end{array}$ & $* \mathrm{H}=(30)$ & Circular & $\begin{array}{l}\text { Mid } \\
\text { Span }\end{array}$ & $* \mathrm{D}=(60)$ & $\begin{array}{l}\text { Circula } \\
\text { r }\end{array}$ & 130 & 30 & 0.009 & 67.796 \\
\hline BT8 & $\begin{array}{l}(1 / 4) \\
\text { depth of } \\
\text { the web }\end{array}$ & $* \mathrm{H}=(30)$ & Circular & $\begin{array}{l}\text { Mid } \\
\text { Span }\end{array}$ & $\begin{array}{c}* A= \\
(40 * 40)\end{array}$ & Square & 130 & 29.25 & $\begin{array}{c}0.008 \\
33\end{array}$ & 63.587 \\
\hline BT9 & $\begin{array}{r}(1 / 4) \\
\text { depth of } \\
\text { the web }\end{array}$ & $* \mathrm{H}=(30)$ & Circular & $\begin{array}{l}\text { Mid } \\
\text { Span }\end{array}$ & $* \mathrm{D}=(40)$ & $\begin{array}{r}\text { Circula } \\
\mathrm{r}\end{array}$ & 130 & 32 & $\begin{array}{c}0.007 \\
33\end{array}$ & 66.32 \\
\hline
\end{tabular}

*A=Area of Opening, * D= Diameter of Opening, *H=Diameter of Hollow, * = Compressive Strength

\section{OBSERVATIONS AND RESULTS}

It was observed that, there was warping cracks at the cracked torque stage; because of it was subjected to very high torque caused cracks, warped around the section and distributed along the beams. Figure 1, show the cracks pattern for all tested specimens, specimen number 1, represent the reference tested beam, the cracks occurred when the first 
increment of the load was applied, and both increased as the test progressed. The beam cracks start diagonally at 45 degrees from support. Measurements of twisted angle in all the tests that are plotted, against the crack torque showed in Figure 4 and also Figure 5, show the behavior of crack torque vs. angle of twist. Figure 6, show the variation of twisted angle with applied distance torque. The general behavior of all tested beams that the beams are loaded predominately in torsion and there are no combined stresses. At low applied torque, the angle of twist to small because of the displacement developed very small, and there is no cracking was appearing. When the loading increasing, the first cracks was starting from support diagonally at 45 degrees. When the torque increased, the cracks become more and visible as warping, in shape around the geometry along the span of beams. The results listed in Table (6), indicated that, the presence of web opening make the torque cracks less, that is mean the presence of opening reduce the strength of beam. In beam number 4 , there is a big hole and the result indicated that, the first crack torque become small, because of developed plastic hinge there.

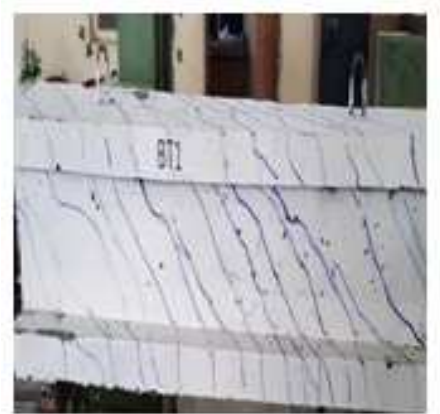

Beam No. BT1

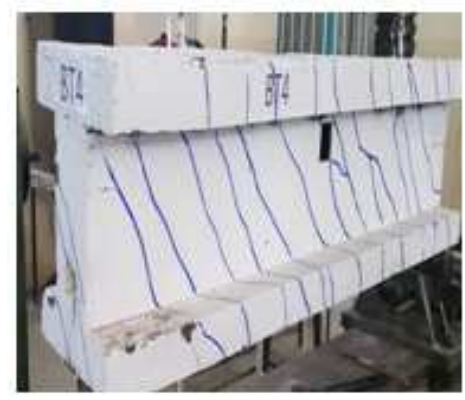

Beam No. BT4

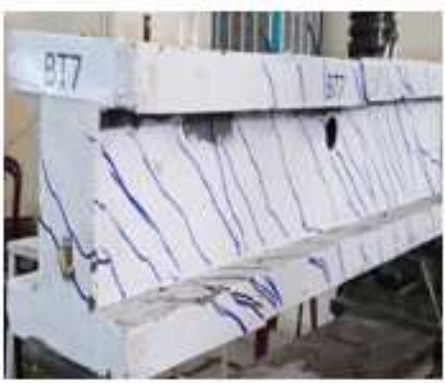

Beam No. BT7

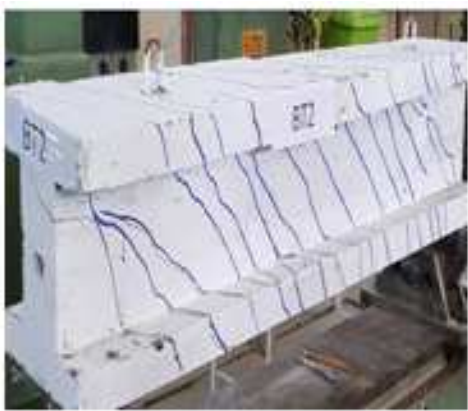

Beam No. BT2

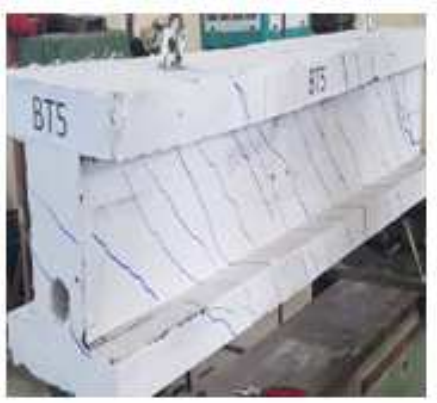

Beam No. BT5

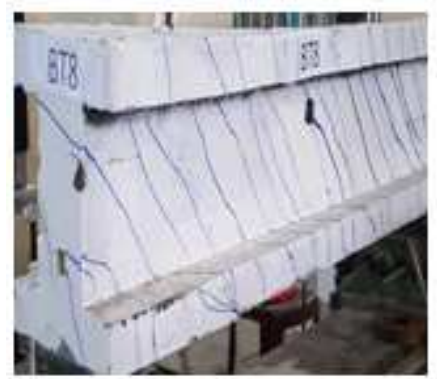

Beam No. BT8

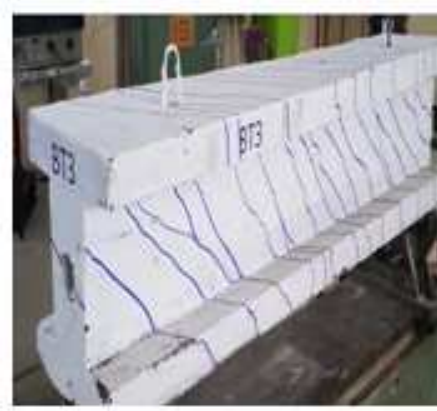

Beam No. BT3

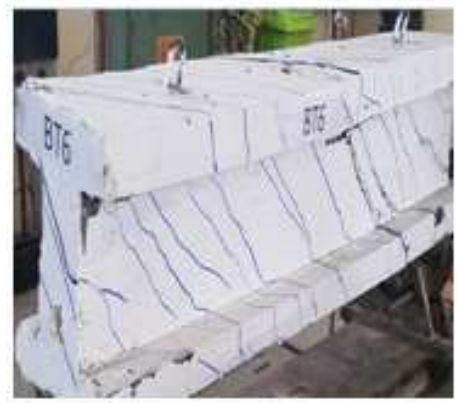

Beam No. BT6

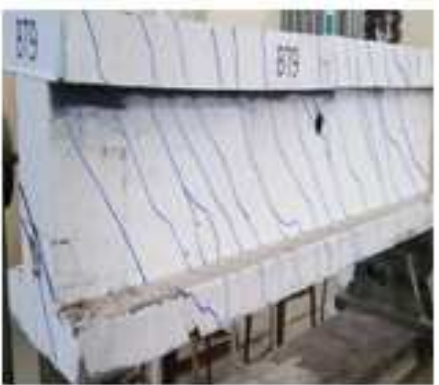

Beam No. BT9

Figure 4: Cracks Propagations for all Tested Beams 


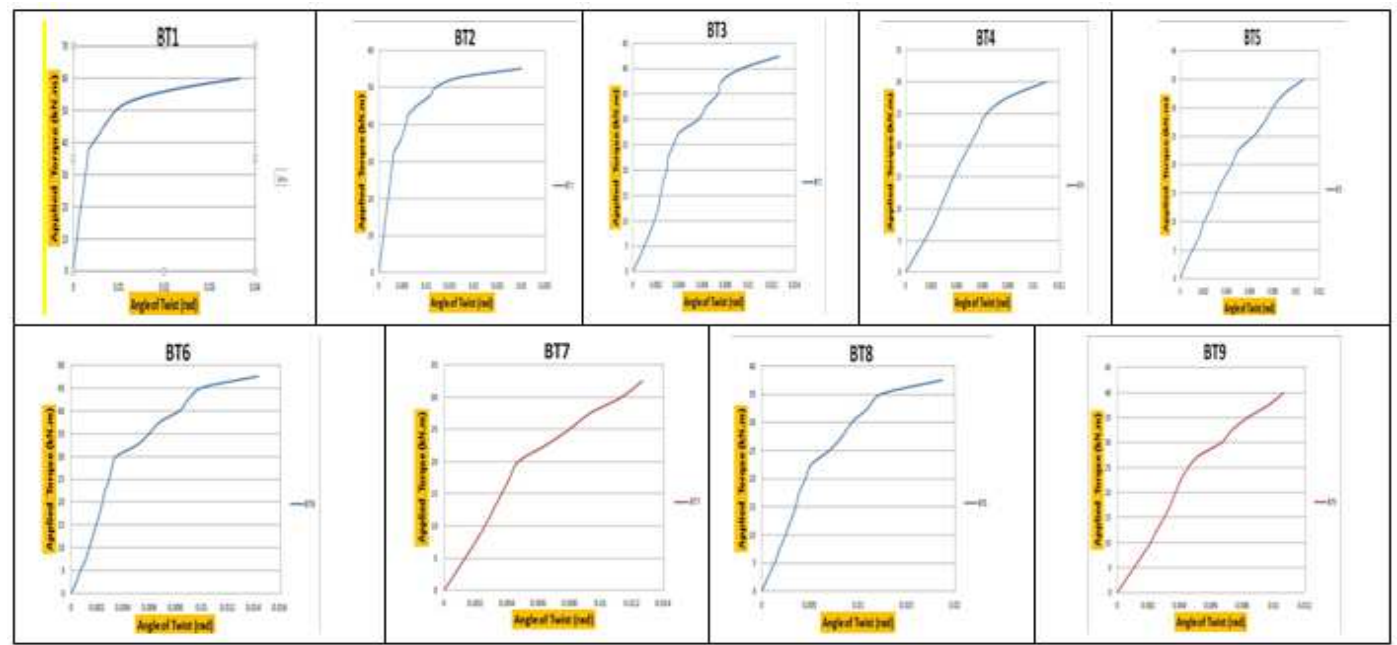

Figure 5: Cracks Torque - Angle of Twist Behavior for all Tested Beams

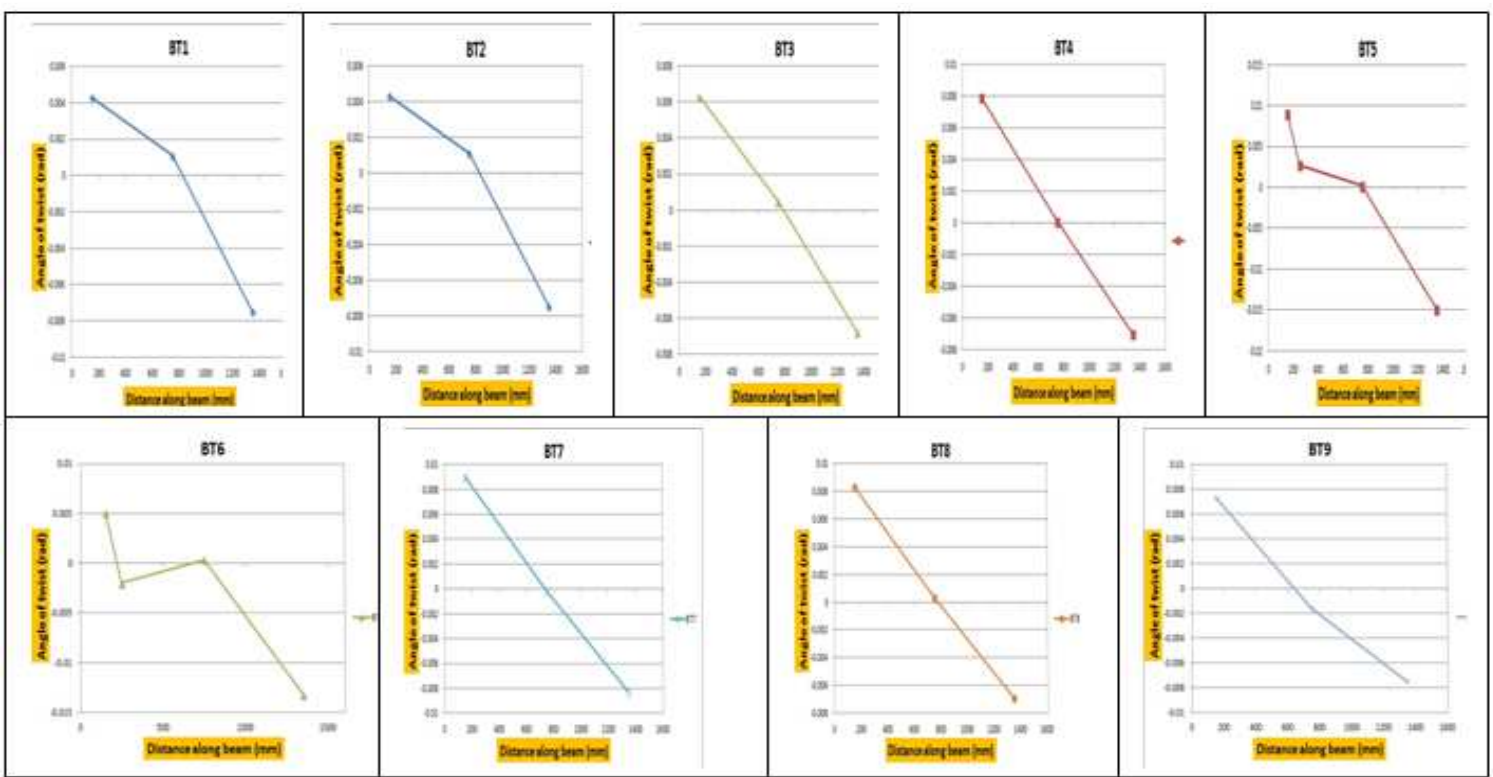

Figure 6: Angle of Twist - Distance Behavior for all Tested Beams

\section{CONCLUSIONS}

According to the results from experimental tests, the following conclusions were drawn:

- The crack torques need to cause first crack decrease in presence of opening.

- $\quad$ The crack torques decrease when the opening increased.

- Cracks density increased as the opening increased and become non-uniform.

- Cracks intensity becomes more at the location of eccentric opening.

- The angle of twist depends on the hollow location at the cracking torque or ultimate crack.

- Increasing the hollow beam size reduces cracking torque and ultimate torque, and corresponding twisted angles. 


\section{REFERENCES}

1. Building Code Requirements for Structural Concrete (ACI 318-14), An ACI Report, Reported by ACI Committee 318.

2. Hisham Mohamed et. al, "Behavior of RC T-Beam Hollow and Solid Section with Reactive Powder Concrete under Pure Torsion", Journal of Engineering and Development, Vol.19, No.2, March, 2015.

3. Waleed Awad et. al, "Torsional Behavior of Reinforced Concrete Hollow Core Beams", Journal of Engineering and Development, Vol.20, No.2, March. 2015.

4. Hisham M. et. al, "Proposed Expressions for Torsional Capacity of RPC Beams", Journal of Engineering and Development Vol.19, No. 3, March 2015.

5. Ali Sabah Ahmed Alamli et al., "Cracks Torque of T Section R.C Beam with Web Perforation using Reactive Powder Concrete", International Journal of Civil, Structural, Environmental and Infrastructure Engineering Research and Development (IJCSEIERD), Volume 6, Issue 3, May - June 2016, pp. 21-28

6. Haneen Maad, "Behavior of High Strength Self Compacted Hollow Section Reinforced Concrete Beams under Pure Torsion", Tikrit Journal of Engineering Sciences 22(1) (2015), 9-23.

7. Wissam Kadhum, "Structural behavior of reinforced reactive powder concrete T-beams under pure torsion", $P h D$ thesis, $A l$ Mustansiriya University, 2013.

8. Raid I. Khalel, "Torsional Behavior of High-Strength Reinforced Concrete Beams", Journal of Engineering and Development, Vol. 17, No.1, March, 2013.

9. Raed Hamed Dakhel, "Effect of the Use of Steel Fibers and Self-compacting Concrete on the Behaivor of Reinforced Concrete Beams Subjected to Pure Torsion", MSc thesis, Al-Mustansiriya University, 2012.

10. Wameedh Ghassan, "behavior of reinforced reactive powder concrete beams in torsion", PhD thesis, University of technology 2010.

11. Iraqi Specification (IQS) No.5/1984, "Portland Cement".

12. Iraqi specification (IQS) No.45/1984, “Aggregate from Natural Sources for Concrete and Construction”.

13. ASTM 1240-04“Standard Specification for Silica Fume used in cementitious mixture”.

14. ASTMC494"Standard Specification for Chemical Admixtures for Concrete".

15. ASTM A615/615M-13, "Standard Specification for Deformed and Plain Carbon Structural Steel Bars for Concrete Reinforcement". 
